\title{
Analysis of the functioning of public benefit organizations in the Podkarpackie and Pomorskie voivodeships acting for environmental protection
}

\author{
Krzysztof Jamroży ${ }^{1}$, Alicja Micał ${ }^{1}$, Dagmara Migut ${ }^{2}$ \\ ${ }^{1}$ University of Rzeszów, Faculty of Sociology and History, Institute of Sociology, Rejtana 16c, Rzeszów, Poland \\ ${ }^{2}$ University of Rzeszów, Faculty of Biology and Agriculture, Department of Agricultural and Food Production Engineering, \\ Ćwiklińskiej 1, Rzeszów, Poland \\ Corresponding author: krzysztofjamrozyur@gmail.com
}

DOI: 10.31708/spi3.2018/jamr.cns18

\section{Introduction}

Organizations acting for environmental protection are often referred to as non-governmental organizations (NGO) (Lonc \& Kantowicz, 2005). They are considered one of the oldest and strongest branches of NGOs in Poland (Smolnicki, 2002). In connection with a wide range of entities that can act to protect the environment and the role they play in civil society, it was decided to include the Podkarpackie and Pomorskie public benefit organization (PBO) (Act of 24 April 2003 on public benefit and voluntary work, 2003) scientific research in order to compare their functioning

\section{Materials and Methods}

The research used the method of desk research, which is based on analyzing the records of available data sources, including in particular their compilation, mutual verification and processing (Bednarowska, 2015). The research tool used in the analytical process were substantive reports of public benefit organizations, available on the website of the National Institute of Freedom ("Sprawozdania OPP - Narodowy Instytut Wolności," n.d.). Their use allow to obtain the latest publicly available data (for 2017) on the functioning of the Pomeranian and Podkarpackie NGO and their mutual compilation. The research sample was selected in a targeted manner, which means that all public benefit organizations working for environmental protection having headquarters in the Podkarpackie or Pomeranian Voivodeships were selected for the research.

\section{Results}

The surveyed NGO having their headquarters in the Podkarpackie Voivodeship most often operate in the area of the commune (5-41.7\%). Seven analyzed PBO $(58.3 \%)$ stated that as part of their activities it does not cross the border of several poviats, which may indicate the local nature of the impacts of the discussed PBOs.

Public benefit organizations having their headquarters in the Pomeranian Voivodeship most often operate throughout the country (4-30.8\%). 9 of analyzed PBOs $(69.2 \%)$ operate at least on the area of the voivodeship, which proves the regional coverage of the PBOs studied. The average number of members of the analyzed NGOs organization in the Podkarpackie Voivodeship is 24 people, and in Pomeranian - 19. While analyzing the examined $\mathrm{PBO}$ in terms of the number of volunteers, it can be noted that in the Podkarpackie Voivodeship their average number is 15 people, and in the Pomeranian Voivodeship - 9. The obtained results may indicate greater public involvement in the activities of ecological non-profit entities in the Podkarpackie Voivodeship. It may be influenced by the local nature of the impacts of the discussed NGOs.

The average number of people who work on employment contracts and civil law contracts in the studied PBO is about 14 (Podkarpackie province) and 16 (Pomorskie Voivodeship). There is no significant difference between the studied regions in this matter.

\section{Discussion}

Research results related to the range of local NGOs activities in the case of the Podkarpackie Voivodeship are confirmed (Gumkowska \& Herbst, 2005). However, the situation is different in the Pomeranian Voivodeship, where PBO usually operate at the regional level.

According to the research carried out by P. Adamiak, B. Charycka and M. Gumkowska (Adamiak, Charycka, \& Gumkowska, 2018), it follows that on average, an association has 30 members. Analyzed organizations has average 24 members of the organization in the Podkarpackie voivodeship and 19 in the Pomeranian. This may means that fewer people are involved directly in the activities of environmental NGOs than in other branches of the third sector.

Nationwide research on the average number of volunteers in NGOs showed that it is usually 8 people. In the case of the Pomorskie Voivodeship, these results are convergent (9 people), however, in the context of the Podkarpackie Voivodeship it is almost twice as large (15 units involved) (Przewłocka, Adamiak, \& Herbst, 2013). 
Analyzes carried out by Przewłocka et al., 2013 indicate that the average number of employees in the organization of the third sector is 3 people. In the Podkarpackie Voivodeship, NGO employs an average of 14 people, and in Pomorskie - 16. Explanation of this phenomenon requires the use of in-depth studies that could show the reason for this condition. It may be assumed that this is related to NGO's finances.

\section{References}

Act of 24 April 2003 on public benefit and voluntary work (2003). Warsaw: The Council of Ministers.

Adamiak, P., Charycka, B., \& Gumkowska, M. (2018). Polskie organizacje pozarządowe 2015 (1st ed.). Warsaw: Klon/Jawor Association.

Bednarowska, Z. (2015). Desk Research - Exploiting the Potential of Secondary Data in Market and Social Research. Marketing i Rynek, (7), 18-26.

Retrieved from http://yadda.icm.edu.pl/yadda/element/bwmeta1.el ement.ekon-element-000171377871

Gumkowska, M., \& Herbst, J. (2005). Wybrane typy organizacji pozarządowych. In A. Gałązka (Ed.), Elementarz trzeciego sektora (pp. 71-79). Warsaw: Klon/Jawor Association.

Lonc, E., \& Kantowicz, E. (2005). Ekologia i ochrona środowiska : podręcznik dla studentów. (M. Grabski \& S. Bielawska, Eds.),

http://www.pwsz.com.pl (1st ed.). Wałbrzych: Wydawnictwo Państwowej Wyższej Szkoły Zawodowej im. Angelusa Silesiusa. Retrieved from http://www.dbc. wroc.pl/dlibra/docmetadata?id=210 33\&from =publication

Przewłocka, J., Adamiak, P., \& Herbst, J. (2013).

Podstawowe fakty o organizacjach

pozarządowych: raport z badania 2012.

Warszawa: Stowarzyszenie Klon/Jawor.

Smolnicki, K. (2002). Organizacje ekologiczne. In K. Smolnicki \& M. Szykasiuk (Eds.), Informator o stanie środowiska Wrocławia (pp. 173-181). Dolnośląska Fundacja Ekorozwoju.

Sprawozdania OPP - Narodowy Instytut Wolności. (n.d.). Retrieved from

https://www.niw.gov.pl/opp/sprawozdania-opp/ 